\title{
Role of Proteins on the Electrochemical Behavior of Implanted Metallic Alloys, Reproducibility and Time-Frequency Approach from EIS (Electrochemical Impedance Spectroscopy)
}

\author{
Geringer Jean and Navarro Laurent \\ Center for Health Engineering, Biomechanics and Biomaterials Department, \\ Bio-Tribocorrosion lab, UMR CNRS 5146, IFR 143, \\ Ecole Nationale Supérieure des Mines de Saint-Etienne, ENSM-SE
}

France

\section{Introduction}

Metallic alloys are commonly used in orthopedic implants. Some attempts were investigated for replacing the human organs or joints. Without being exhaustive, some key points of the history of the orthopedic implants could be presented (Callaghan, 2007):

- In 1826, the first pseudoarthrosis was practiced by J. Barton with a wood piece of the hip joint;

- $\quad$ In 1891, the first femoral head in ivory was implanted by T. Gluck (Gluck, 1890);

- In 1923, the "Molded arthroplasty" using hollow hemisphere made of glass was practiced by M.N. Smith-Petersen;

- In 1936, the first acrylic femoral stem was implanted by Judet's brothers.

One might suggest the implanted materials are close to the organic materials in terms of natural origin. The last one, acrylic polymer, would be a dedicated material because their mechanical properties are close to the ones of bone. However the mechanical and tribological properties are not sufficient for being enough resistant. Thus the metallic implants were investigated because of their better mechanical properties, elastic modulus and tensile strength. Following, few important dates are suggested:

- In 1938, M.N. Smith-Petersen used the Vitallium ${ }^{\circledR}$ made of Co-Cr-Mo, CobaltChromium-Molybdenum, alloy for the femoral stem;

- In 1949, Judet's brothers implanted the first total hip arthroplasty (Judet, 1949);

- Finally, in 1962, Sir J. Charnley imposed the low friction arthroplasty with a femoral stem made of 316L stainless steel (Charnley, Livingstone, 1970; Charnley, Springer, 1970).

Finally 3 main materials are implanted as femoral stem or metallic components: the titanium alloy, Ti-6Al-4V, the stainless steel, 316L SS, and the cobalt-chromium alloy (Park, 1992). The first one is dedicated to the femoral stem, the second one is used as material for manufacturing femoral stem, metal back and possibly the head for Metal on Polymer, MoP, 
contact, the third metal could be investigated as the Head and cup assembly for Metal on Metal, MoM, assembly, the head component for MoP assembly and no frequently the femoral stem. Figure 1 highlights the different assemblies involved in the femoral stem. The ceramic material will not be presented in this work.

From this point, we will focus on the metallic alloys that are involved in implants and specifically hip implants. Obviously metallic materials are not originally exhibited in human body. The interactions with human organic substances, proteins, phosphate ions and so on, should play a key role in the materials lifetime. The physical and chemical reactions are numerous and the passivity of the metallic alloys is submitted to the influence of the liquid medium. Some electrochemical investigations were carried out for understanding and predicting the passivity of alloys.

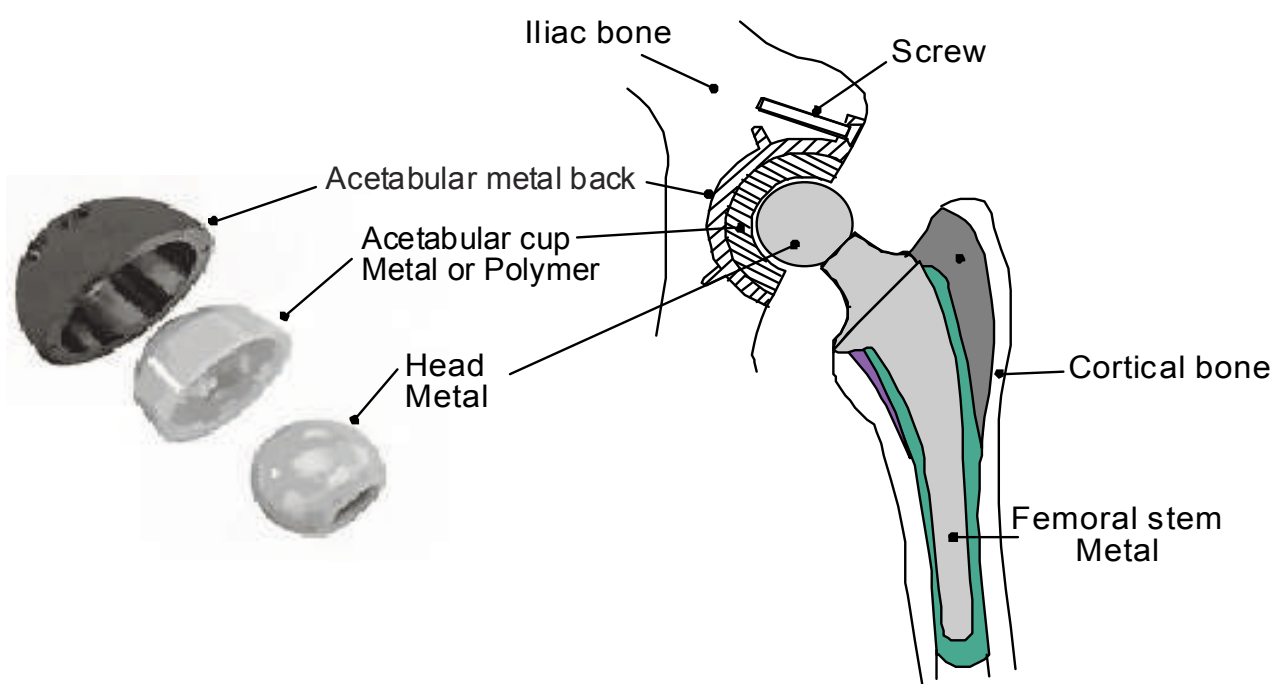

Fig. 1. Scheme of a femoral stem and the components

Normally the materials are fixed in the bone by adhesion of cells as osteoblasts. Due to the difference of mechanical properties between materials in contact (femoral stem of 316L and femoral bone for instance), the debonding is promoted during human gait (Pellier, 2011). The difference of the elastic modulii is of the order of magnitude of 100 . Thus the friction under small displacements, i.e. the fretting corrosion (Barril, 2002; Bethune, 1968; Eden, 1911; Geringer, 2005; Geringer, 2006; McDowell, 1953; Tomlinson, 1927; Tomlinson, 1939; Uhlig, 1954; Waterhouse, 1955; Waterhouse, 1980), could occur. One will not pay attention on this point in this work. However it is worth noting that fretting corrosion is the topic of research works. Thus some investigations are in progress for understanding the role of proteins on the lifetime of metals that are submitted to fretting. Finally we will focus our attention only on the passivity of the alloy submitted to pure corrosion.

Understanding corrosion reactions and factors that promote the corrosion degradations is a challenging goal. The titanium alloy is particularly interesting because of this 
biocompatibility. Cells and tissues adhere friendly to this metallic alloy (Dowson, 1981; Bronzino, 1995). The surface state, it means the roughness, of the titanium alloy material plays a significant role on the passivity. Indeed, polished surfaces of Ti-6Al-4V involve a decreasing of the current density, 2 orders of magnitude, in distilled water at $22^{\circ} \mathrm{C}$ (Kirbs, 2003). However, in Phosphate Buffered Solution (PBS), at $22^{\circ} \mathrm{C}$, the potential of corrosion is close to $-300 \mathrm{mV} / \mathrm{SCE}$ (Standard Calomel electrode) and no effect of the roughness was highlighted (Kirbs, 2003). The investigations about the proteins effect were pointed out with synovial liquid, coming from joint puncture of human patients, bovine serum and urine. Finally the passivity was the worst one for the synovial liquid compared to the other media (Hsu, 2004). These experiments were carried out at different temperatures and the current density increases, i.e. the passivity decreases, when the temperature of electrochemical investigations increases (Hsu, 2004). About the local mechanisms of adsorption and corrosion, the double layer, i.e. the first layer of adsorbed species and ions on the surface of the pristine metal, is constituted by hydroxyl ions. The charge transfer occurs through this layer. The proteins promote the diffusion of metallic cations for $\mathrm{pH}$ lower than 7 . Beyond 7 , i.e. between 7 and 9, the proteins play the role of protective layer against the dissolution of metal. The layer on the metal surface is mechanically less resistant than the one after dousing in solution of proteins, results coming from the measurement of hardness (Khan, 1999).

The Electrochemical Impedance Spectroscopy, EIS, is a useful tool to describe the close interface between metal and solution (Dygas, 1999; Harrington, 2001; Macdonald, 1998; Orazem, 2004). This experimental technique allows modeling the electrical circuit constituting by metal-interface-solution thanks to the impedance measurements, i.e. the transfer function between the imposed voltage, imposed physical parameter, and the measured current density, measured parameter. The most basic electrical circuit is constituted by the $\mathrm{R}_{\text {sol }}$ (resistance of the solution) in serie with an association in parallel with a polarization resistance, $R_{\mathrm{pol}}$, and a capacitor, $\mathrm{C}$, or a constant phase element, $\mathrm{Q}$, to take into account the non uniform behavior of the capacitor, $R_{\text {sol }}\left(R_{\text {pol }} / / C\right)$. This circuit highlights one time constant and one interface is modeled. Two time constants indicate a layer that is constituted by two interfaces. From this useful kind of investigations, two time constants were highlighted on the Ti-6Al-4V alloy: the first layer is the thickness of oxides and the second one is the adsorbed proteins (Pan, 1996; Tamilselvi, 2006). When a solution constituted by phosphate ions, from PBS solution, and proteins, the equivalent electrical circuit with two constant times fits well (Zaveri, 2008). A competitive adsorption does exist between the one of phosphate ions and the one of proteins. Consequently the EIS measurements could be interpreted differently due to close experimental conditions but the reproducibility is not studied (Ouerd, 2007; Zaveri, 2008)). To conclude on this part, it is worth noting that the quantity of the adsorbed proteins was investigated. On pristine pure titanium, the quantity of proteins is within the range of 1.8 and $2.89 \mu \mathrm{g} . \mathrm{cm}^{-2}$, in a solution of proteins and phosphate ions at $37^{\circ} \mathrm{C}$ (Cai, 2006; Yan, 2008). These results were obtained thanks to measuring by UV spectrometry the quantity of free proteins in solution, taking into account the known quantity of initial concentration of proteins. The adsorbed concentration of proteins was determined by the difference between the initial and the free concentration of proteins. The same type of investigations was carried out except about the measurement of the concentration of the adsorbed proteins (Payet, 2008). This measurement was carried out thanks to a quartz microbalance. The authors found a value of $0.71 \pm 0.07$ $\mu \mathrm{g} . \mathrm{cm}^{-2}$. The gap between both values is about 3 or 4 . The non direct measurement technique 
should involve a huge discrepancy compared to the second one. Moreover the surface state is not controlled in these experiments. This key point should be relevant for this kind of investigations. Finally in order to improve the corrosive resistance of the Ti-6Al-4V a coating should be added on the surface, i.e. TiN (Liu, 2003). The problem of this approach is that sometimes the coating is not biocompatible.

In this section, we will present the passive behavior of $\mathrm{Co}-\mathrm{Cr}$ and 316L alloys from bibliographical results. Numerous experiments were carried out on the $\mathrm{Co}-\mathrm{Cr}$ alloys. The passivity of Co-Cr-Mo alloy with proteins, bovine serum or albumin, and phosphate ions was hugely investigated thanks to EIS experiments. In a Phosphate Buffered Solution, the Co-Cr-Mo alloy exhibits an enrichment of the chromium content of the oxides film. The Cobalt is dissolved preferentially compared to the other elements (Ouerd, 2008). For solution constituted by bovine serum and phosphate ions, the polarization resistance increases when the concentration of phosphate ions increases. It is worth noting that the bovine serum does not play any significant role on the corrosion of the $\mathrm{Co}-\mathrm{Cr}$ alloy. No obvious impact of the bovine serum was highlighted. The competitive adsorption, ions and proteins, was investigated by Munoz et al (Munoz, 2007). The phosphate ions influence the corrosion resistance of the Co-Cr alloy. The highest is the concentration of phosphates; the highest is the corrosion resistance. To confirm the previous study (Ouerd, 2008), the present study does not show an influence of proteins. The state of the passive film does hugely influence the action of proteins. Finally, the inhibitor role of phosphate, resp albumin, was found to be anodic, resp. cathodic for $\mathrm{Co}-\mathrm{Cr}$ and 316L SS (Valero, 2008). About the polarization resistance, the effect of albumin is opposite on both metallic alloys. This protein decreases the polarization resistance for $316 \mathrm{~L}$ and it decreases the resistance of $\mathrm{Co}-\mathrm{Cr}$. Both metallic alloys are not sensitive to the albumin effect. The passivation state of the metallic alloys, before the tests, should play a significant role on the effect of proteins on the alloy.

To conclude, numerous factors are involved in the electrochemical behavior of the metallic alloys. Moreover the time dependence of the proteins effect was not really investigated. We suggest studying the influence of proteins and ions with different solutions. Thus the time dependence, i.e. the time-frequency response, for a couple of metallic alloy/solution should provide significant results for understanding the influence of proteins. The physiological liquid contains phosphate ions in the PBS solution; this kind of solution will be studied. The hip implant could be tested with the ISO 14242 close to the actual conditions. Thus the bovine serum, in this typical test, contains sodium azide. This salt and specifically the ions $\mathrm{N}_{3}$ - could involve a different reaction related to corrosion of the metallic alloy. We will pay attention on this specific point.

\section{Materials and methods}

\subsection{The materials}

The investigated metallic alloys are Ti-6Al-4V, titanium alloy, Co-Cr-Mo alloy and the 316L, stainless steel alloy. The Table 1 exhibits the composition of these alloys. They were obtained by spark optical emission spectrometry. The compositions are related to the specifications of ASTM F136 for Ti-6Al-4V (TA6V), ASTM standards: ASTM A240 for 316L stainless steel alloy; and finally ASTM F1537 for Co-Cr alloy. The measured compositions are in agreement with the ones from the ASTM standards, except for 316L alloy for which the Ni content is $4 \%$ higher than the maximum value. 
Ti-6Al-4V alloy

\begin{tabular}{cccccccccc} 
Elements & $\mathrm{Al}$ & $\mathrm{V}$ & $\mathrm{Fe}$ & $\mathrm{O}$ & $\mathrm{Cr}$ & $\mathrm{Ni}$ & $\mathrm{C}$ & $\mathrm{N}$ & $\mathrm{Ti}$ \\
\hline $\begin{array}{c}\text { Composition } \\
(\% \text { w/w or } \\
\text { ppm })\end{array}$ & $5.91 \%$ & $3.87 \%$ & $\begin{array}{c}1096 \\
\mathrm{ppm}\end{array}$ & $\begin{array}{c}1038 \\
\mathrm{ppm}\end{array}$ & $\begin{array}{c}137 \\
\mathrm{ppm}\end{array}$ & $\begin{array}{c}125 \\
\mathrm{ppm}\end{array}$ & $\begin{array}{c}124 \\
\mathrm{ppm}\end{array}$ & $\begin{array}{c}53 \\
\mathrm{ppm}\end{array}$ & $\mathrm{Bal}$ \\
\end{tabular}

316L SS

\begin{tabular}{ccccccccccc} 
Elements & $\mathrm{Cr}$ & $\mathrm{Ni}$ & $\mathrm{Mo}$ & $\mathrm{Mn}$ & $\mathrm{Si}$ & $\mathrm{Cu}$ & $\mathrm{C}$ & $\mathrm{P}$ & $\mathrm{S}$ & $\mathrm{Fe}$ \\
\hline $\begin{array}{c}\text { Composition }(\% \\
\mathrm{w} / \mathrm{w})\end{array}$ & 17.05 & 14.55 & 2.80 & 1.73 & 0.40 & 0.10 & 0.02 & 0.02 & $<0.01$ & Bal.
\end{tabular}

\section{Co-Cr-Mo alloy}

\begin{tabular}{ccccccccc} 
Elements & $\mathrm{Cr}$ & $\mathrm{Mo}$ & $\mathrm{Mn}$ & $\mathrm{Si}$ & $\mathrm{Ni}$ & $\mathrm{C}$ & $\mathrm{Al}$ & $\mathrm{Co}$ \\
\hline $\begin{array}{c}\text { Composition }(\% \\
\mathrm{w} / \mathrm{w})\end{array}$ & $28.50 \%$ & $5.87 \%$ & 0.78 & 0.46 & 0.25 & 0.037 & 0.02 & $\mathrm{Bal}$
\end{tabular}

Table 1. Composition of the metallic alloys.

The final polishing step after manufacturing samples is a key step for controlling the surface state and especially the roughness that could play a significant role on the corrosion reactions. Following steps were carried out on metal samples: the abrasive grid paper 4000, the $6 \mu \mathrm{m}, 3 \mu \mathrm{m}$ and $1 \mu \mathrm{m}$ diamond paste with around duration of 5 minutes.

\subsection{Solutions}

Table 2 exhibits the compositions of the chosen solutions. Six solutions, desionized water, Ringer solution, Phosphate Buffered solution (PBS), PBS + bovine serum, PBS + bovine

\begin{tabular}{|c|l|l|l|l|l|l|l|l|l|}
\hline $\begin{array}{c}\text { Weight } \\
\text { concentration } \\
\text { g.L-1 }\end{array}$ & $\mathrm{NaCl}$ & $\mathrm{KCl}$ & $\mathrm{CaCl}_{2}, 2 \mathrm{H}_{2} \mathrm{O}$ & $\mathrm{NaHCO}_{3}$ & $\mathrm{KH}_{2} \mathrm{PO}_{4}$ & $\mathrm{Na}_{2} \mathrm{HPO}_{4}$ & Albumin & $\begin{array}{c}\text { Bovine } \\
\text { serum }\end{array}$ & $\mathrm{NaN}_{3}$ \\
\hline $\begin{array}{c}\text { Solution 1 } \\
\text { desionized water }\end{array}$ & & & & & & & & \\
\hline $\begin{array}{c}\text { Solution 2 } \\
\text { Ringer solution }\end{array}$ & 8,500 & 0,250 & 0,220 & 0,150 & & & & & \\
\hline $\begin{array}{c}\text { Solution 3 } \\
\text { PBS solution }\end{array}$ & 8,192 & 0,223 & & & 0,136 & 1,420 & & & \\
\hline $\begin{array}{c}\text { Solution 4 } \\
\text { PBS+Alb } \\
\text { solution }\end{array}$ & 8,192 & 0,223 & & & 0,136 & 1,420 & 1,000 & & \\
\hline $\begin{array}{c}\text { Solution 5 } \\
\text { PBS + serum }\end{array}$ & 8,192 & 0,223 & & & 0,136 & 1,420 & & 18,5 & \\
\hline $\begin{array}{c}\text { Solution 6 } \\
\text { PBS + serum + } \\
\text { NaN }\end{array}$ & 8,192 & 0,223 & & & 0,136 & 1,420 & & 18,5 & 1,000 \\
\hline
\end{tabular}

Table 2. Constituents of the 6 investigated solutions; PBS: Phosphate Buffered solution, Alb: Albumin, serum: bovine serum or calf serum, $\mathrm{NaN}_{3}$ : Sodium azide 
serum $+\mathrm{NaN}_{3}$ (sodium azide) allow testing the influence of ions, the pure albumin (Albumin fraction $\mathrm{V}$ extracted from bovine serum, model protein) and the proteins from bovine serum (calf serum heat inactivated, PAA, triplicated filtering with a porosity of 0.1 $\mu \mathrm{m})$. This last solution is the reference solution for testing the prosthetic hip implant according to the ISO standard 14242. Sodium azide is mentioned in this procedure as an antioxidant for preventing the degradations of the bovine serum. It is constituted by $74 \mathrm{~g} . \mathrm{L}^{-1}$ of total proteins. More precisely the serum contains 35 g.L-1 of albumin, 9 g.L. $\mathrm{L}^{-1}$ of $\alpha$-globulin, 11 g.L. ${ }^{-1}$ of $\beta$-globulin and 19 g.L $L^{-1}$ of $\gamma$-globulin. The bovine serum was diluted by 4 in the studied solution. The temperature of experiments was of $37 \pm 1{ }^{\circ} \mathrm{C}$ during all electrochemical measurements. To conclude these solutions were selected because they highlight the potential interest for studying the corrosion resistance (Geringer, 2007).

\subsection{Electrochemical conditions}

The table 3 summarizes the relevant elements about the electrochemical device. The key points are the sizes and the positioning of the electrodes, working and counter electrodes

Potentiostat

Size of the working electrode, WE

Reference electrode, RE

Counter electrode, CE

Distance RE-WE

Volume of solution

$\mathrm{pH}$ of solution

Temperature

Device with thermostat
Parstat 2263

$7.07 \mathrm{~cm}^{2}$; diameter of $30 \mathrm{~mm}$

SCE; $0.250 \mathrm{~V} / \mathrm{SHE}$

Platinium wire, circle with a

diameter of $25 \mathrm{~mm}$

$10 \pm 2 \mathrm{~mm}$

$60 \pm 2 \mathrm{~mL}$

$7,6 \pm 0,1$

$37 \pm 1{ }^{\circ} \mathrm{C}$

Double wall

Table 3. Experimental conditions; SCE: Standard Calomel Electrode; SHE: Standard Hydrogen Electrode

From the bibliographical study, the adsorption effect of phosphates ions and proteins is confused. It depends from the conditioning of the materials, polishing, storage, and first step of the electrochemical conditions. Consequently a particular attention was paid on this first step because it will determine the further chemical and electrochemical reactions. Before performing the following experiments of EIS, a cathodic polarization was carried out for each test.

Finally four types of experiments were performed:

1. Applied potential $-1 \mathrm{~V} / \mathrm{SCE}$ during 5 minutes

2. Free corrosion potential or Open Circuit Potential, $\mathrm{OCP}$, during 2 hours, conditioning of the materials

3. Loop that will be repeated 120 times:

4. EIS, from $100 \mathrm{kHz}$ to $0 \mathrm{~Hz}, 20 \mathrm{pts}$ /decade, voltage amplitude of $\pm 10 \mathrm{mV}$, Data quality of 15 (Influence on the duration of measurements), Open circuit potential is the potential of measurement

5. OCP during $2 \mathrm{~min}$

6. OCP during 26 hours

The Data quality parameter plays a significant role on the reproducibility of measurements. The increasing of this parameter involves the increasing of the number of the measurements. 
For a same frequency and a couple of $(\mathrm{U}, \mathrm{I})$, the duration of measurements increases but the ratio signal/noise decreases. Considering this point, the measurements are more accurate than the usual ones without working with high Data quality value. Moreover the experiments were repeated 3 times, exactly in the same conditions, experiences and quality of measurements. The double wall, electrical connections, samples and the electrodes (working and counter) are isolated from outside waves by a Faraday cage. Moreover the potentiostat performed measurements with a floating mass for avoiding the leakage current. Finally, a particular attention was paid on the statistical analysis. As we mentioned, the triplicated measurements (new samples and new measurements) allow involving an average value and a standard deviation. The reproducibility was thus investigated.

\section{Raw results}

\subsection{Comparison of the results in the $X-Y$ plane}

The Figure 2 a) shows the Nyquist Diagram from a sample of Ti-6Al-4V immersed in desionized water. The time $0 \mathrm{~h}$ is related to the $3^{\text {rd }}$ sequence and the $1^{\text {st }}$ experiment of EIS, i.e. after 2 hours of Open Circuit Potential. The time 12.5 his related to the $120^{\text {th }}$ experiment of EIS. The electrochemical behavior is different according to the time. The capacitive loop decreases. The oxides layer and the double layer protect less the metal against corrosion. The Figure $2 \mathrm{~b}$ ) highlights the evolution of the module and the phases for the same experiment. In the frequency range, the evolution of the module does not exhibit any significant change. On the contrary, the phase decreases slightly from the first to the $120^{\text {th }}$ experiment at low frequencies. The evolution of the phase is more accurate than the one of the module.

The huge interest for presenting 120 experiments is getting information about the kinetic evolution of the competitive effect of adsorption of ionic species, phosphates and chlorides, and the organic species, albumin and proteins more generally in the bovine serum. However graphics are not common. It is the reason why 3D graphics are suggested in this study. The plane is time-frequency ( $\mathrm{X}-\mathrm{Y}$ plane) and the $\mathrm{Z}$ coordinates are the modules or the phases thanks to a Matlab ${ }^{\circledR}$ program from raw data. From Figure $2 b$ ), it is possible to get the Figure $3 a$ ) and the Figure $3 b$ ) is the projection in the X-Y plane time-frequency. The module, for instance, will be presented in ohm, $\Omega$, and the surface was equal for each experiment to $7.07 \mathrm{~cm}^{2}$.

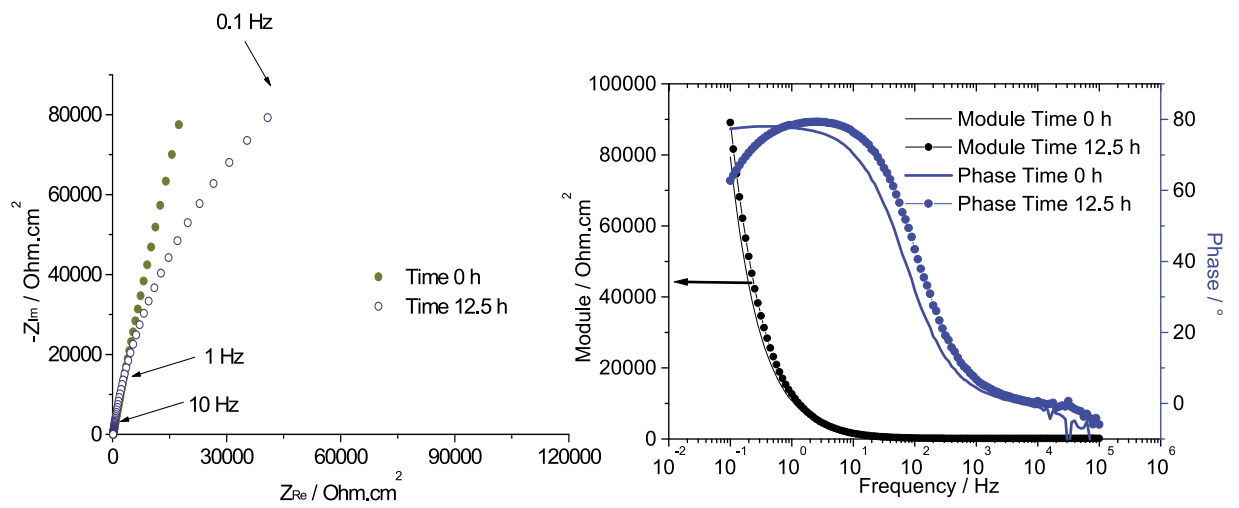

Fig. 2. Nyquist diagram related to a sample of Ti-6Al-4V in desionized water; time $0 \mathrm{~h}$ : $1^{\text {st }}$ experiment of EIS; time 12.5h: $120^{\text {th }}$ experiment of EIS; b) Modules and phases of the same experiment 

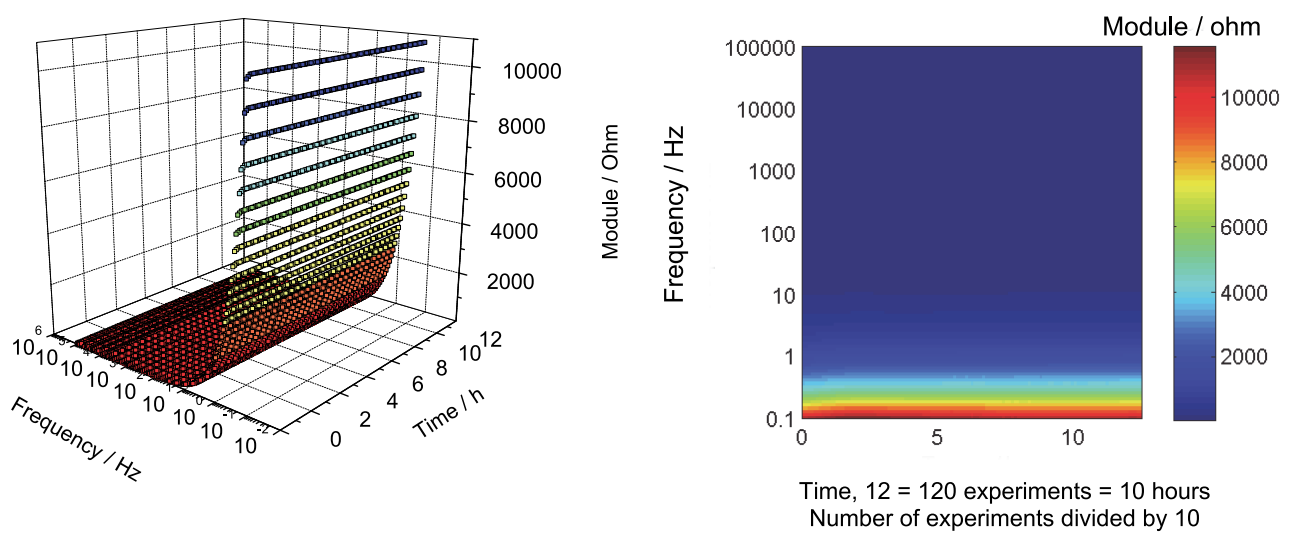

Fig. 3. a) Evolution of the average module (3 experiments) from EIS experiments in desionized water vs. time and vs. frequency; b) Evolution of the average module in desionized water, projection in the plane time-frequency, color corresponds to the module

Thus one might suggest to represent the evolution of modules, phases and the variation coefficient or the coefficient of variation (standard deviation divided by the average value) of the three experiments obtained in the same conditions. The comparison was carried out between the 6 solutions that were presented in the Table 2. The experiments in the desionized water will be considered as the reference ones. The differences between the modules of solutions 2 to 6 and the reference solution, solution 1, will be presented in order to compare the evolutions according to the time. Only the significant results will be presented in this study.

\subsection{Results from Ti-6Al-4V; 316L; Co-Cr-Mo}

First of all, the results from the Ringer solution and the desionized water are the same. Thus the media with PBS + serum and PBS + serum $+\mathrm{NaN}_{3}$ do not exhibit significant differences. Consequently these media will not be compared in this study

\subsubsection{Ti-6Al-4V}

First of all, the results from the Ringer solution and the desionized water are the same. Consequently they will not be compared in this study. The Figure 4a) shows the evolution of the modules in the plane time-frequency for the 120 experiments. The results for the frequencies higher than $10 \mathrm{kHz}$ exhibit the highest values of the variation coefficient. The value is not so significant, i.e. always lower than the one at $1 \%$. However this trend is always the same for all metals, see Figure 6a) and Figure 8a).

However the Figure 5a) exhibits the difference between the average value of the module in the considered medium and the one in desionized water. This particular evolution presents that the difference is always negative. It means that the module in all media is lower than the one in the desionized water. The more the module is high, the more the medium is protective for the considered metal. Consequently the most protective medium is the water for the Ti-6Al-4V. Ions, like in PBS, or ions and proteins, i.e. PBS + Albumin and PBS + serum (calf serum), promote the dissolution of the metal Ti-6Al-4V. 
Role of Proteins on the Electrochemical Behavior of Implanted Metallic Alloys, Reproducibility and Time-Frequency Approach from EIS...

a)

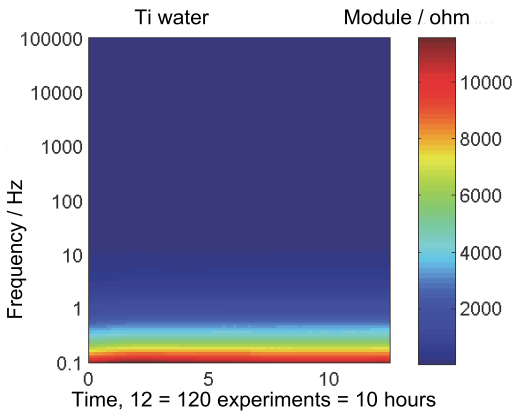

Ti PBS

Module / ohm
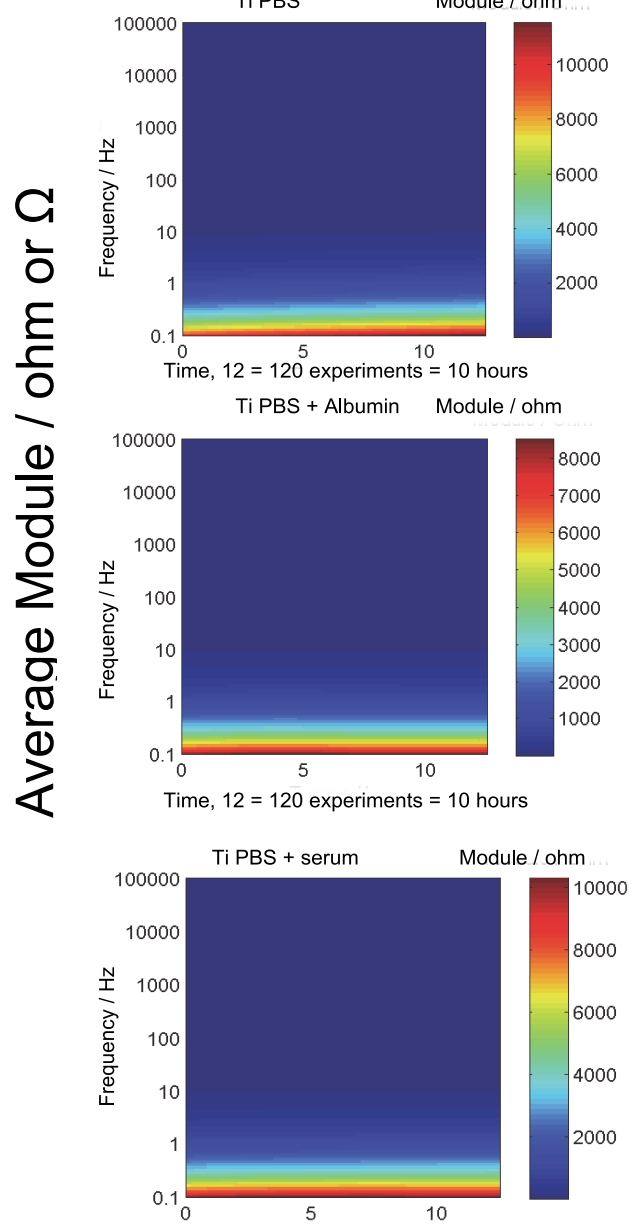

Time, $12=120$ experiments $=10$ hours b)

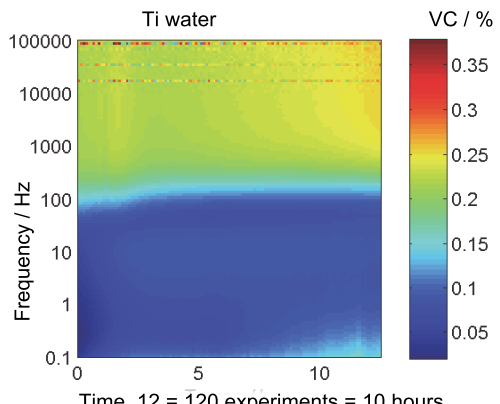

Ti PBS

$\mathrm{VC} / \%$
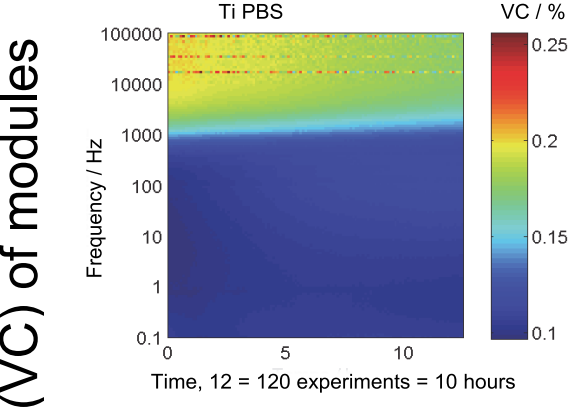

$12=120$ experiments $=10$ hours

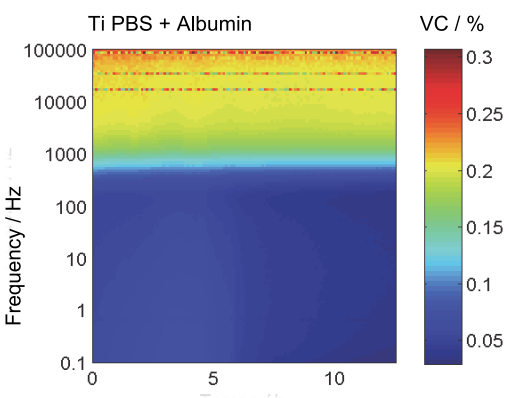

Time, $12=120$ experiments $=10$ hours

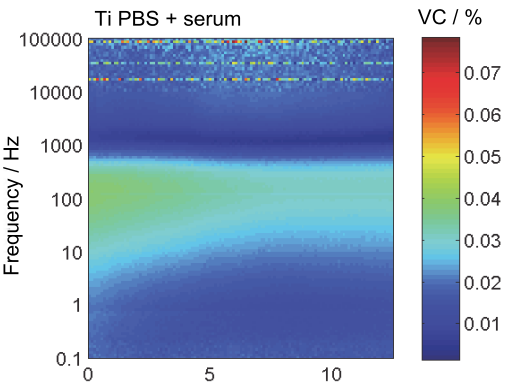

Time, $12=120$ experiments $=10$ hours

Fig. 4. a) average modules from experiments: water (desionized water), PBS (Phosphate Buffered solution), PBS + Albumin, PBS + serum (bovine serum); b) variation coefficient (VC) from the same solutions than a); time-frequency plane; Ti-6Al-4V alloy. 


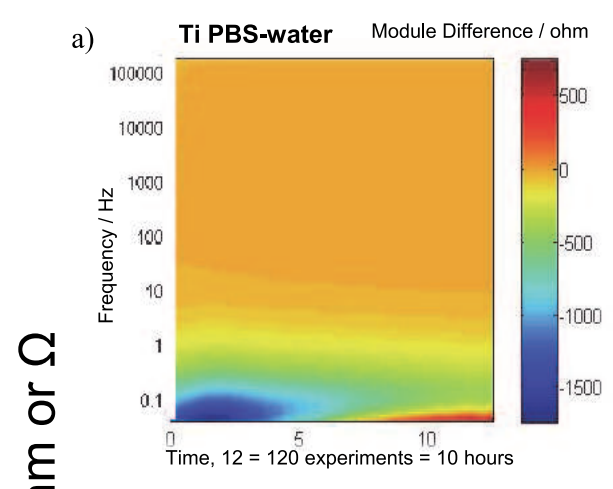

b)
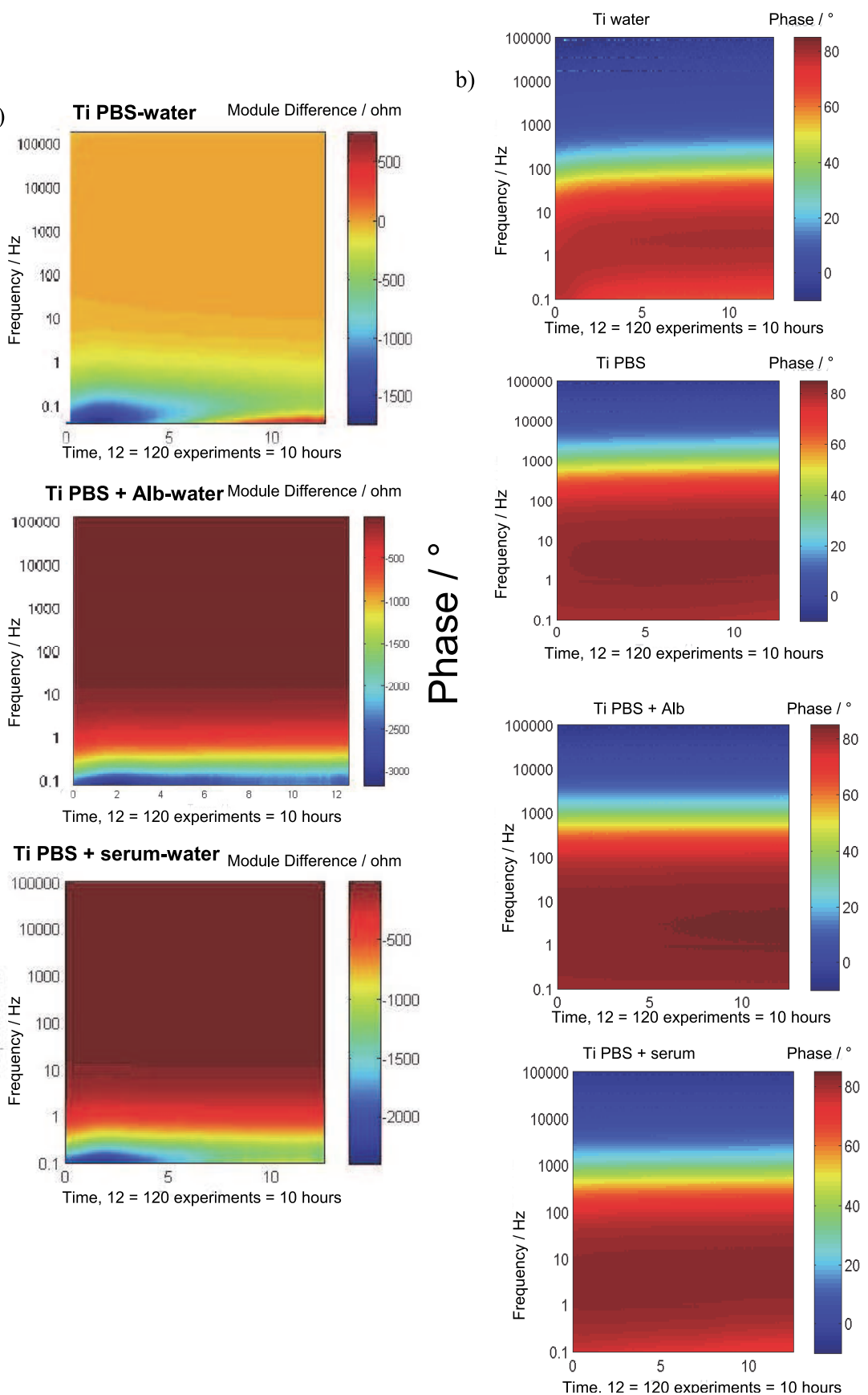

Fig. 5. a) differences of modules for 3 combinations; b) Phase $/{ }^{\circ}$ for; the solutions are the same than the ones from Figure 4; time-frequency plane; Ti-6Al-4V alloy. 
From Figure 5b), the evolution of the phase shows interesting results. The phase reaches a maximum of $90^{\circ}$, related to the behavior of a capacitance, for the desionized solution. However, considering the other media, the phase is maximum, i.e. equal to $80-90^{\circ}$ and it never decreases at low frequencies. One may suggest that the electrochemical behavior is close to a capacitance when the media are PBS, PBS + Albumin or PBS + calf serum.

Thus the module is lower for the Ti-6Al-4V in media with ions and proteins but otherwise the phase is higher in the media with ions and ions + proteins (Albumin or calf serum). The capacitive behavior is promoted by the ions and proteins and the resistance of the electrochemical layer at the surface of the implant made of $\mathrm{Ti}-6 \mathrm{Al}-4 \mathrm{~V}$. The variations are weak because if one extrapolates the data with an equivalent electrical circuit, taking into account the discrepancies of measurements and calculations, no significant evolution of the polarization resistance and the capacitances were highlighted.

This approach shows, for Ti- $6 \mathrm{Al}-4 \mathrm{~V}$, the electrochemical evolution of the surface, during the 10 hours of the experiments, is different: the ions and the combination of ions and proteins decrease significantly the module at low frequencies. Moreover the phase did not decrease even at low frequencies, in media with ions and ions+proteins. The capacitance of the metallic surface is higher in these media than the one in water.

\subsubsection{L SS}

The Figure 6a) shows that the module calculated in the PBS + serum solution is higher than the ones calculated in other solutions. The variation coefficient, Figure $6 \mathrm{~b}$ ), highlights that the desionized water involves the highest discrepancies. The electrochemical system is submitted to fluctuations. One might suggest that the corrosion did not occur continuously. However the ions and the proteins could decrease the random specification of the corrosion process compared to the corrosion in other media.

The difference of modules shows that the PBS + serum - water is positive. Thus the module of this typical experiment is higher than the ones from the water test. Finally the phase highlights the main difference of the electrochemical behavior. The maximum of the phase is reached for the media of PBS + serum and PBS + Albumin at the highest frequency of 100 $\mathrm{Hz}$. For the media PBS, the maximum of the phase is reached around $1 \mathrm{~Hz}$ and it decreases from $1 \mathrm{~Hz}$ to $0.1 \mathrm{~Hz}$. Consequently the capacitive behavior is promoted preferentially in the medium containing the proteins solutions even according to the time. This evolution corroborates the highest modules showed in the Figure 6a). Thus the proteins promote a protective effect on the 316L surface.

\subsubsection{Co-Cr-Mo alloy}

The Figure 8a) presents the evolution of the module for the same media than the previous studies for the Co-Cr-Mo medium. The water, PBS and PBS + Albumin media do not exhibit significant differences for the module evolution. However the PBS + serum medium promotes the highest module. The evolution of the variation coefficient is the lowest for the PBS solution. This medium induces a very good reproducibility. The process of adsorption of proteins should be not delayed. For the other media, the variation coefficient is approximately equal to 0.3-0.4 for the highest values at the highest frequencies.

The Figure 9a) confirms that the results from the Figure 8a). The difference of the modules between PBS + serum and water is positive and it is related to the protective effect of the serum. The Figure 9b) presents the evolution of the phase for the $\mathrm{Co}-\mathrm{Cr}$ alloy. The phase reaches the maximum of $90^{\circ}$ according to the time, i.e. after 2 hours for PBS + Albumin and PBS + serum. 
a)
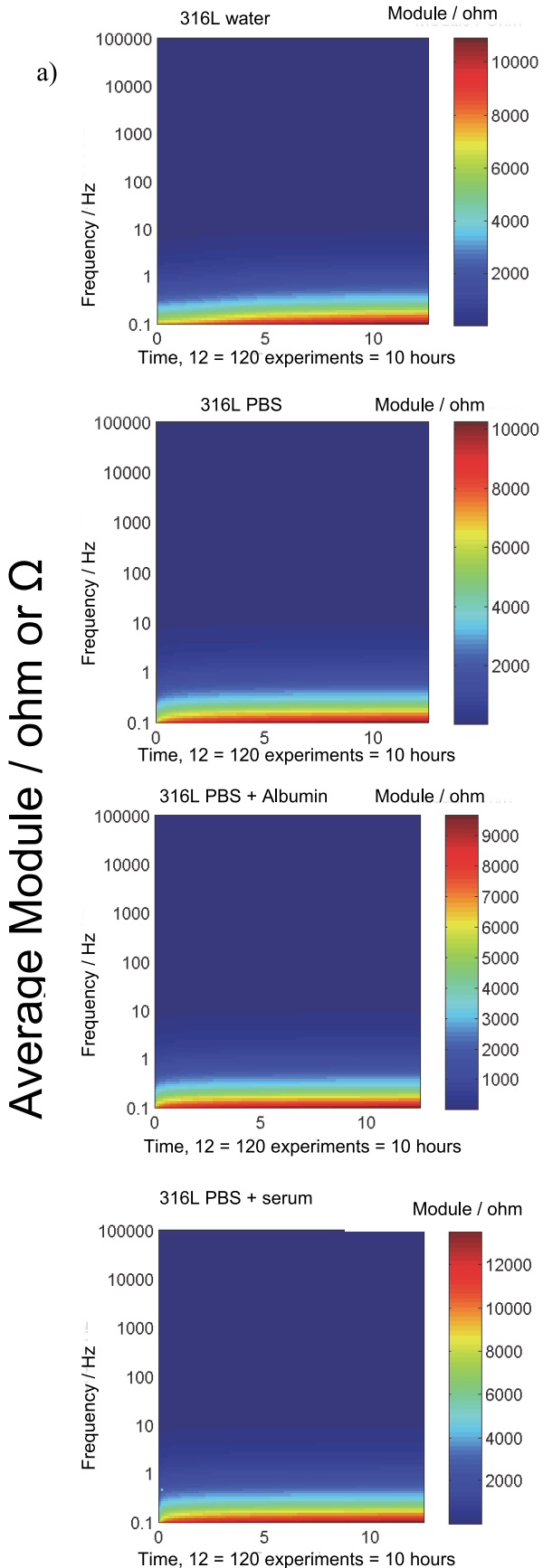

b)
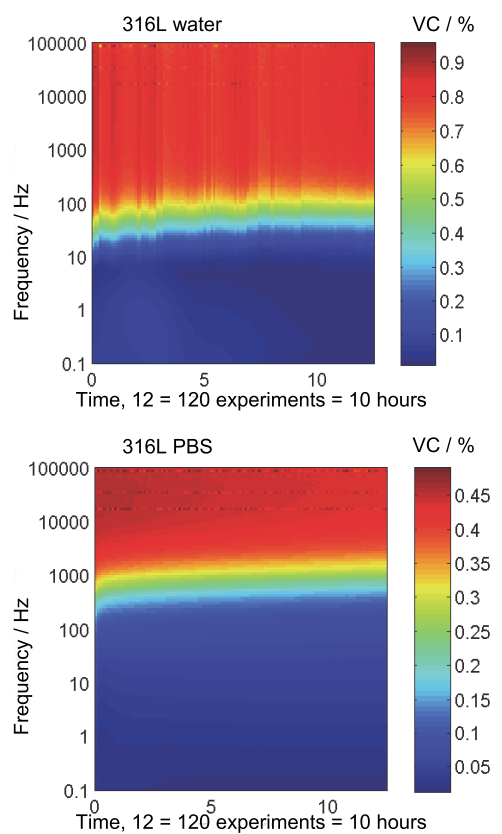

316L PBS + Albumin VC $/ \%$

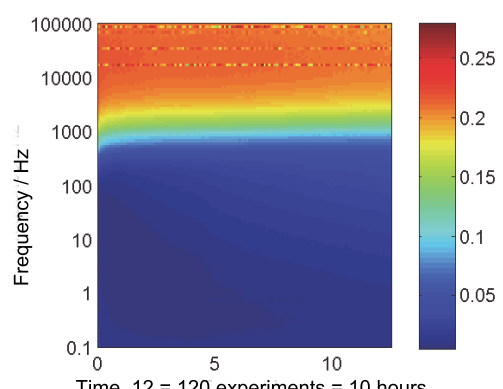

Time $12=120$ exneriments $=10$ hours

316L PBS + serum $\mathrm{VC} / \%$

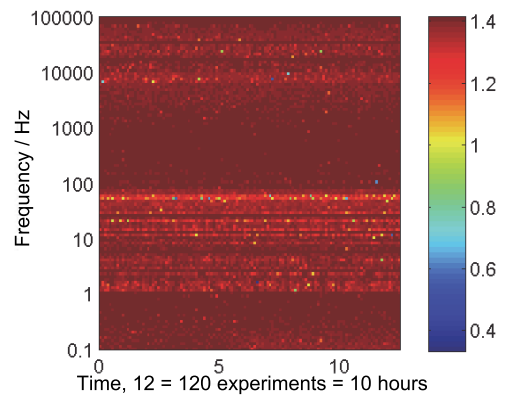

Fig. 6. a) Average modules, same solutions than the Figure 4 ; b) variation coefficient (VC) from the same solutions than a); time-frequency plane; 316L SS alloy. 
Role of Proteins on the Electrochemical Behavior of Implanted Metallic Alloys, Reproducibility and Time-Frequency Approach from EIS...

a)

316L PBS-water Module Difference / ohm

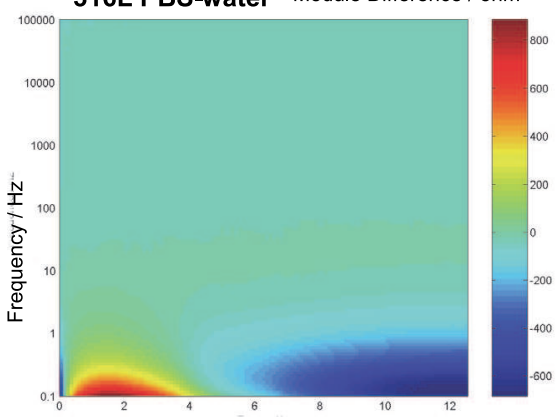

Time, $12=120$ experiments $=10$ hours
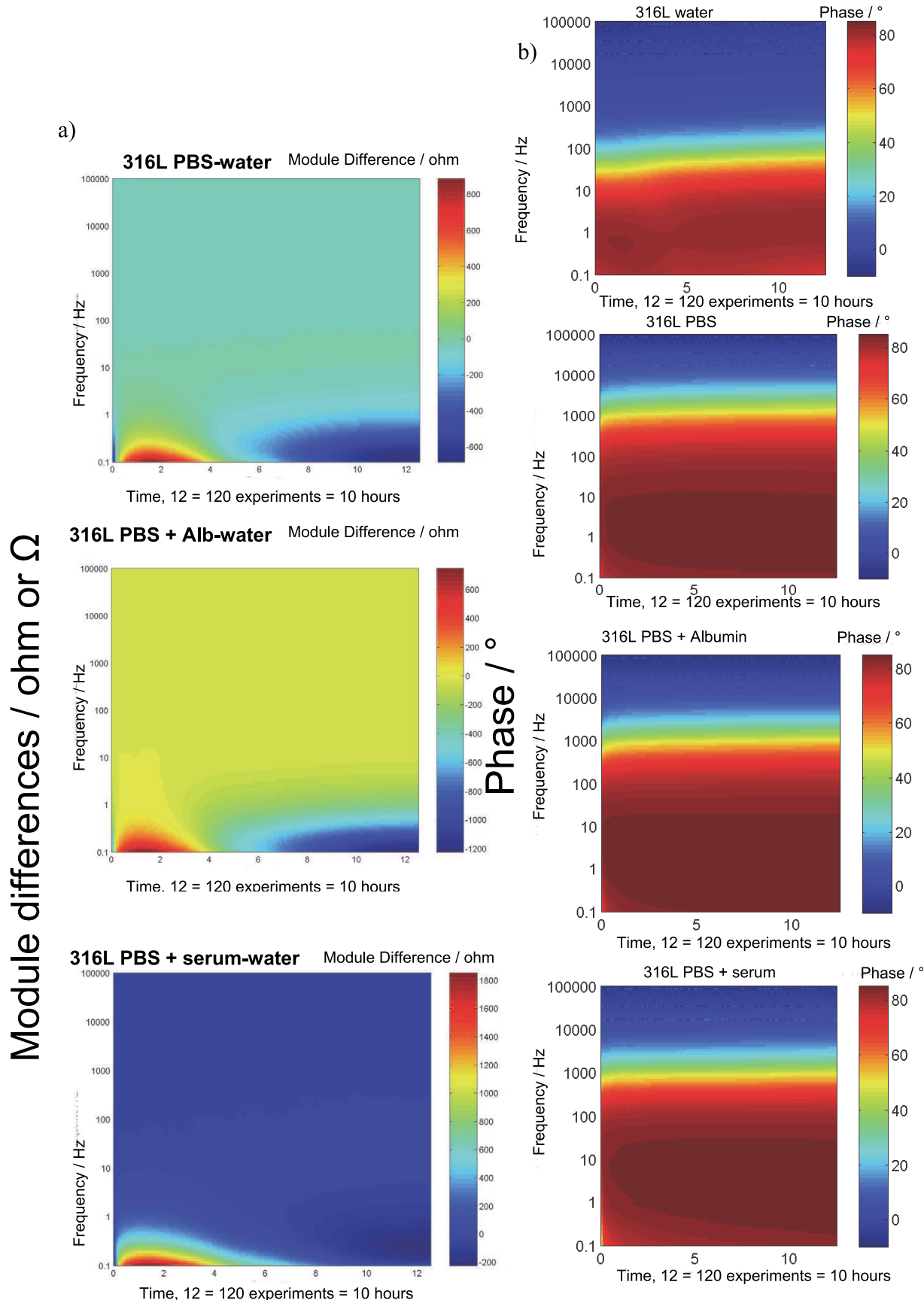

Fig. 7. a) differences of modules for 3 combinations; b) Phase $/{ }^{\circ}$ for; the solutions are the same than the ones from Figure 4; time-frequency plane; 316L SS alloy. 

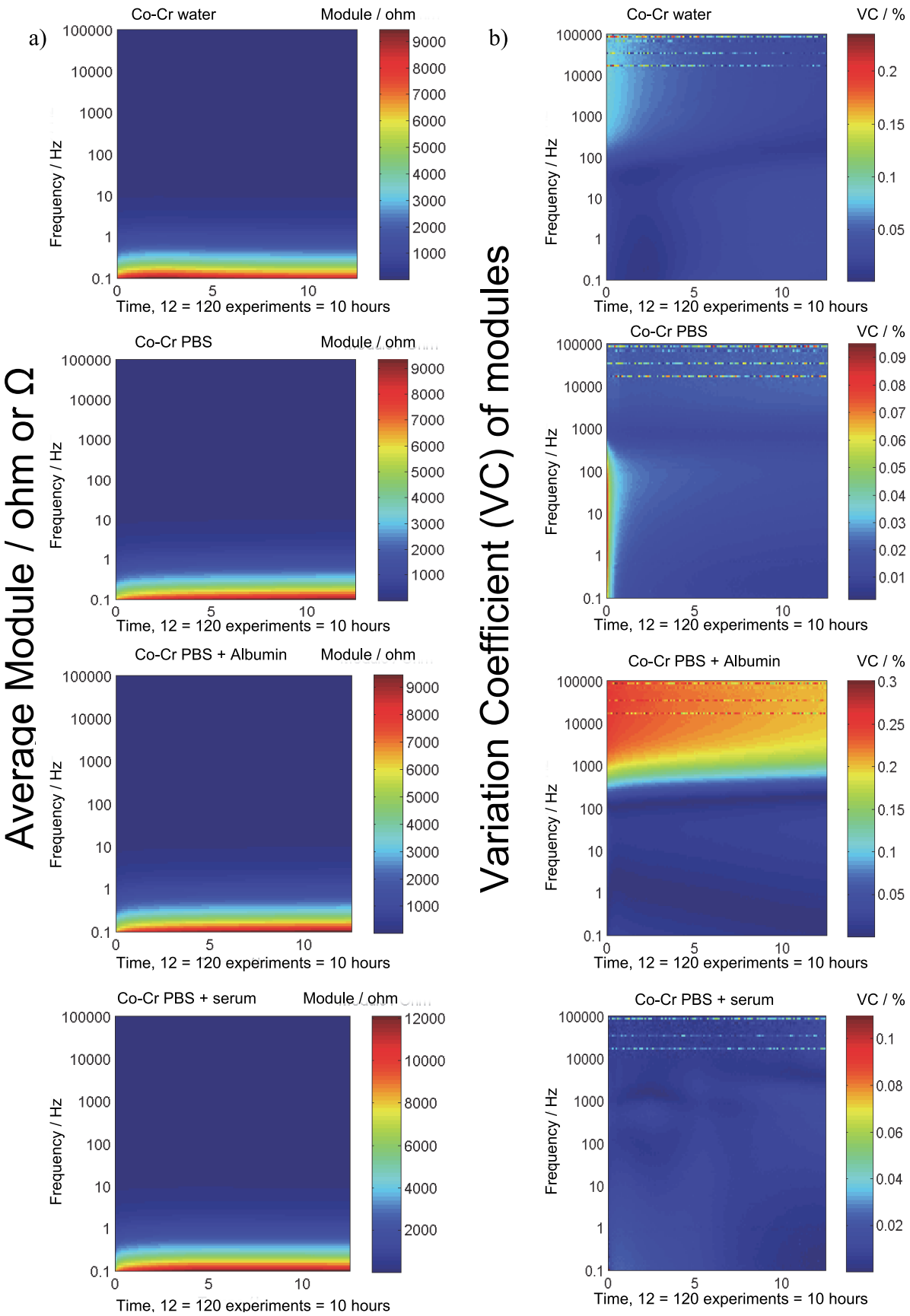

Fig. 8. a) Average modules, same solutions than the Figure 4; b) variation coefficient (VC) from the same solutions than a); time-frequency plane; Co-Cr alloy. 
Role of Proteins on the Electrochemical Behavior of Implanted Metallic Alloys, Reproducibility and Time-Frequency Approach from EIS...

a)
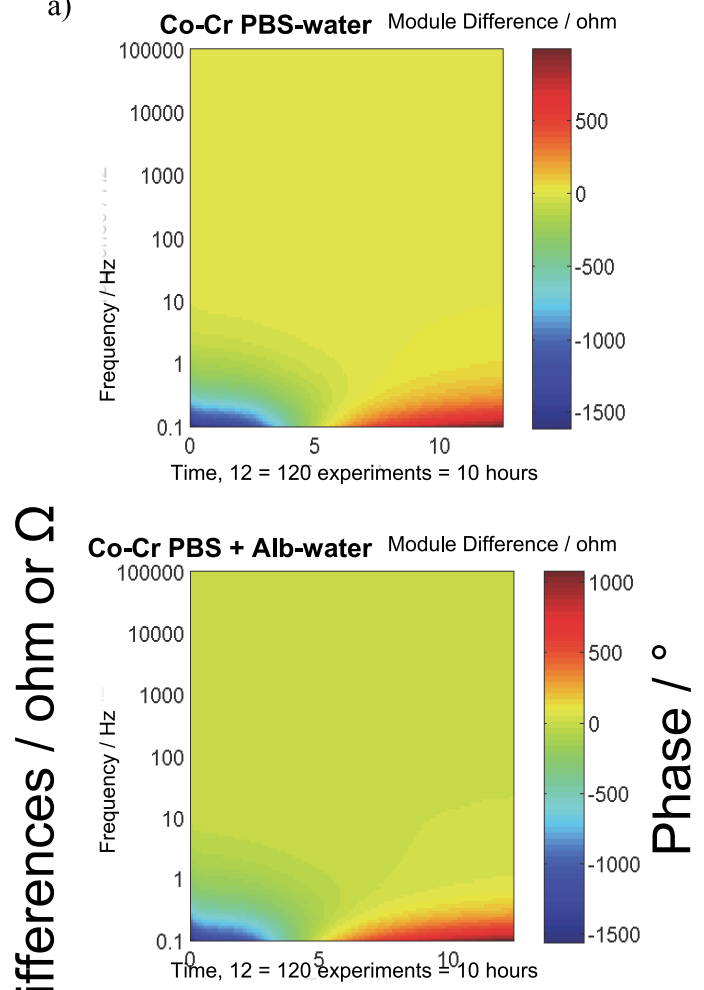

$\frac{\infty}{\frac{0}{2}}$

Co-Cr PBS + serum-water Module Difference / ohm

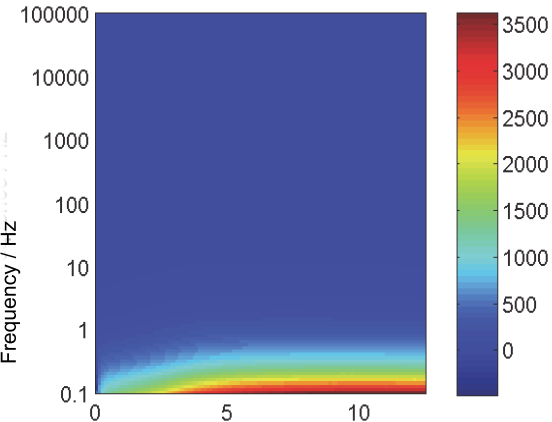

Time, $12=120$ experiments $=10$ hours b)
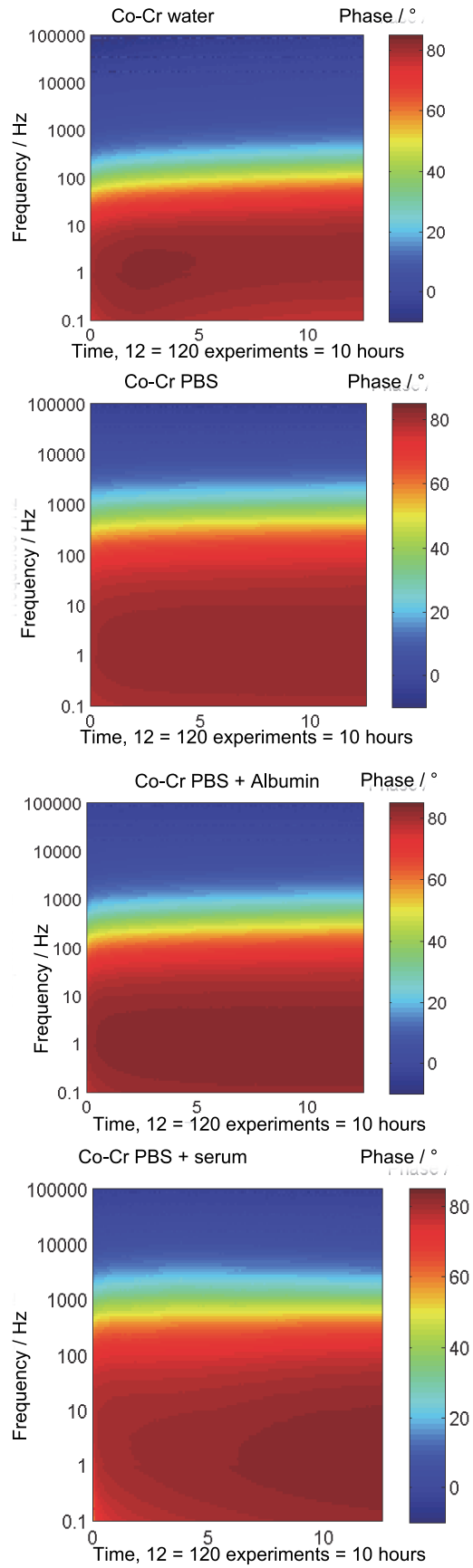

Fig. 9. a) differences of modules for 3 combinations; b) Phase $/{ }^{\circ}$ for; the solutions are the same than the ones from Figure 4; time-frequency plane; $\mathrm{Co}-\mathrm{Cr}$ alloy. 
Finally the most protective medium is PBS + serum for the Co-Cr-Mo alloy and the 316L SS due to the highest modules, the difference is the highest between modules of PBS+ serum and modules of water for these two alloys. The highest modules differences are the ones of Co-Cr-Mo. This result confirms the approach of Valero et al ${ }^{40}$. Additionally the phase is the highest too for the combination PBS + serum and Co-Cr-Mo and PBS + serum and 316L. This typical evolution corroborates the conclusion from the evolution of the modules. On the contrary, the Ti-6Al-4V seems to be the less protected in the media with proteins, negative difference of modules. These results confirm the choice of 316L SS and Co-Cr-Mo alloys that have the better corrosion resistance in a medium with proteins. These evolutions are assessed by the time evolution and the particular time-frequency 3D graphs. For both alloys, taking into account the time-frequency evolution of the modules differences and the one of the phases, the most significant information of the EIS investigations is highlighted. Distinguishing the corrosion behavior of alloys is quite possible. From this study, the alloys are ranked from the less protected to the more protected: Ti-6Al-4V $<316 \mathrm{~L}<\mathrm{Co}-\mathrm{Cr}-\mathrm{Mo}$.

\section{Biocorrosion of implants - Discussion and future directions}

The new approach, suggested in this work, shows relevant results from the investigations according to the time-frequency plane. A study of reproducibility, a minima, 3 tests, is necessary for highlighting the right evolution. We described a tool from EIS investigations for better understanding the behavior of metal in solution. This method could be used at applied potentials and with different solutions or coatings on surfaces that could be issued from usual materials or biological materials as cells.

The role of proteins is relevant for the corrosive behavior of metals, the results presented in this work highlights these key points. The following investigations should be focused on the influence of cells on the corrosive behavior of metals. Due to the reactions of cells submitted to stress, electrical or mechanical, some oxidative species could be produced, especially the Reactive Oxidative Species, ROS. It has been showed the corrosion resistance of the Co-Cr alloy is lower with macrophages cells from Lin et al (Lin-Journal of Orthopedic Research, 2004). The ROS species, as $\mathrm{H}_{2} \mathrm{O}_{2}$, promote the corrosion of the $\mathrm{Co}-\mathrm{Cr}$ alloy. The suggested method in this work should be applied for investigating the time dependence of the cells behavior. Moreover the Ti-6Al-4V alloy is submitted to the same decrease of the corrosion resistance when macrophages are deposited on the alloy surface. The macrophages are liberated when debris or metal ions or metal complexes are released in a corrosive medium in the in vivo behavior. Thus the surface composition of the titanium alloy changes according to the presence of macrophages. Performing the protection of this alloy is more and more difficult with macrophages cells (Lin-Applied Surface Science, 2004). It is worth noting that the presence of chlorides does not promote the resistance against corrosion because the passive film is less protective than the one without chlorides (Marino, 2006). Our study highlights that the Ti-6Al-4V alloy is less protected in a medium containing proteins. It suffers from the comparison with 316L SS and Co-Cr-Mo alloys. Finally the typical study that is focused on the role of cells on the corrosive behavior of metallic alloys should be emphasized with a study with different cells (Oshida, 2007). The corrosive behavior of metallic alloys should be studied in in vivo conditions. The first step should be the corrosion investigations in fresh tissues coming from hip joint for instance. The second step could be related to the animal experiments and measuring the electrochemical behavior should be measured according to the validation of protocols. Finally one might suggest the experiments in human cases. One should think about the electrochemical investigations of 
implants in human body will add actual information about the lifetime of the metallic implants. The tissue is typical to the human body and all reactions are specific to the surrounding environment of an articulation for instance. With these typical experiments ethic problems are significantly highlighted. One should preserve the health state, the safety and the integrity of patients from which the agreement should be obtained. It was mentioned that this kind of experiments was substantially investigated 30 years ago (Steinemann, 1980). For a short duration of experiments, these investigations, in human body, were performed with Nitinol alloy involved in manufacturing stents dedicated for blocked arteries (Pertile, 2008). The short experiments do not allow predicting the corrosive behavior for a long time. The experiments of a long duration should be considered for understanding the corrosive behavior, OCP and EIS investigations.

New alloys are suggested for replacing the bone for instance. Magnesium alloys have the same mechanical properties than the ones of bone. However they are submitted to severe corrosion reactions, one might suggest that this alloy could be completely dissolved for allowing the rebuilding of the bone matrix. Some questions are related to the toxicity of the corrosion reactions and the degradations of products. The scientist and surgical communities pay attention on this risk assessment of this new alloy (Yuen, 2010). Thus some alloys are implanted, Titanium, Co-Cr and 316L SS alloys and implanting new alloys as Magnesium alloys is a huge challenge. One should expect that some investigations are needed about the already implanted alloys. The electrochemical behavior and specifically the corrosion in tissues are not well described according to the time. Consequently the time-frequency analysis should get additional information about the corrosive of these implanted alloys.

In the introduction part, the fretting behavior was highlighted. Indeed about implants, one may suggest that, after debonding between bone and implants, the fretting, friction under small displacements or friction, should be triggered. Some questions are related to the behavior of implants in a physiological liquid with proteins for example. In fretting conditions the degradation of the Ti-6Al-4V alloy does not suffer any effect of proteins. On the contrary, the corrosion rate of the $316 \mathrm{~L}$, submitted to fretting degradations, decreases according to the proteins concentration (Williams, 1988). The same trend was highlighted in the results presented in this paper, without fretting. Moreover the corrosion rate of a 316L submitted to fretting corrosion decreases with the concentration of albumin ${ }^{7}$. The future directions about this kind of investigations are related to the role of proteins for a better understanding and the role of cells, specifically the ROS on the corrosion and the frictioncorrosion (and fretting-corrosion) investigations.

Finally one should pay attention on the electrical equivalent circuit. Normally the Nyquist diagrams, from EIS analyses, could be interpreted thanks to an electrical equivalent circuit, $R_{\text {sol }}\left(C / / R_{\text {pol }}\right)$, for example. More complex electrical circuits could be investigated for interpreting the diagrams, especially Warburg impedance that is dedicated to simulate the diffusion of species. Each time, the point is: is the electrical circuit relevant with the electrochemical interface at the metal surface? As we did not practice additional investigations about the oxides film or the layer on the metal surface, we prefer to draw conclusions from the modules and the phases and not on the evolutions of the electrical components of the non realistic circuit.

\section{Conclusions and outlooks}

This work was dedicated to study the corrosion resistance of the metallic alloys with synthetic solutions for mimicking the physiological liquid. A new approach allows 
describing the evolution of modules and phases in the plane time-frequency. These graphs become from the Electrochemical Impedance Spectroscopy investigations.

The results show significantly that the Ti-6Al-4V alloy is the less protected alloy. The Co-Cr alloy seems to be the most resistant. Moreover the proteins allow increasing the passivity of Co-Cr and 316L alloys. The new approach highlights the particular evolution according to the time. Thus the electrochemical behavior is stabilized after 5 hours. The best material, from this study, is the Co-Cr alloy, about the electrochemical behavior.

The corrosion resistance in a physiological liquid is the first element about the quality of an implanted metallic material. Afterwards the behavior during fretting corrosion or friction corrosion is a key point about the lifetime of a metallic implant. The first results, in fretting corrosion 7 , show that proteins decrease the corrosive behavior but it increases the mechanical wear. Understanding the influence of proteins during fretting-corrosion is a goal in next years for all implanted alloys. From the point of view of the understanding of physic phenomena, the synergisms between the mechanical and the corrosive degradations have to be investigated. The corrosive characterization is carried out from this work and the previous ones.

On this related field proteins-metal-friction some investigations are in progress.

\section{Acknowledgement}

The authors are grateful to A. Gault and B. Allirand for manufacturing the electrochemical cell. Moreover they want to acknowledge Pr. D.D. Macdonald for fruitful discussions.

\section{References}

Barril, S.; Debaud, N.; Mischler, S. \& Landolt, D. (2002) A tribo-electrochemical apparatus for in vitro investigation of fretting-corrosion of metallic implant materials. Wear, 252, pp. 744-754.

Bethune, B. \& Waterhouse, R.B. (1968) Electrochemical studies of fretting corrosion. Wear, 12 , pp. 27-34

Bronzino, J.D. (1995) The Biomedical Engineering Handbook, CRC Press, pp. 540-542, Boca Raton Florida

Cai, K.; Frant, M.; Bossert, J.; Hildebrand, G.; Liefeith, K. \& Jandt K.D. (2006), Surface functionalized titanium thin films: Zeta-potential, protein adsorption and cell proliferation. Colloids and Surfaces B: Biointerfaces, 50, pp. 1-8

Callaghan, J.J.; Rosenberg, A.G. \& Rubash, H.E. (2007) The adult hip, Eds Wolters Kluwer Health Lippincott Williams \& Wilkins, pp. 7-14, Philadelphia PA,

Charnley J. (1970) Acrylic cement in orthopaedic surgery, Eds: Livingstone Ltd, Edinburgh, London

Charnley J. (1970) low friction arhtroplasty of the hip, Eds Springer-Verlag, New York

Dowson, D. \& Wright, V. (1981) An introduction to the biomechanics of joints and joint replacement, Eds Mechanical Engineering Publications, pp. 174, London

Dygas, J.R. \& Breiter, M.W. (1999) Variance of errors and elimination of outliers in the least squares analysis of impedance spectra. Electrochimica Acta, 44, pp. 4163-4174

Eden, E.M.; Rose, W.N. \& Cunningham, F.L. (1911) The endurance of metals. Proc. Instn Mech. Engers, 4, pp. 839-974

Geringer, J.; Forest, B. \& Combrade, P. (2005) Fretting corrosion of materials used as orthopaedic implants. Wear, 259, pp. 943-951. 
Geringer, J.; Forest, B. \& Combrade, P. (2006) Wear analysis of materials used as orthopaedic implants. Wear, 261, pp. 971-979

Geringer, J.; Normand, B.; Diemiaszonek, R.; Alemany-Dumont, C. \& Mary, N. (2007) Electrochemical impedance spectroscopy on Co-Cr-Mo alloy in two media simulating physiological liquid. Matériaux et Techniques, 95, pp. 417-426

Gluck T. (1890). Die invaginations methode der Osteo- und Arthroplastik. Berl Klin Wochenschr, 28, pp. 732-736

Harrington, D.A. \& van den Driessche, P. (2001) Stability and electrochemical impedance of mechanisms with a single adsorbed species. Journal of Electroanalytical Chemistry, 501, pp. 222-234.

Hsu, R.W-W.; Yang, C-C.; Huang, C-A. \& Chen, Y-S. (2004) Electrochemical corrosion properties of Ti-6Al-4V implanet alloy in the biological environment. Materials Science and Engineering A, 380, pp. 100-109

Judet, R. \& Judet, J. (1949), Essais de reconstruction prothétique de la hanche après résection de la tête fémorale. Journal de chirurgie, 65, pp. 17-24

Khan, M.A.; Williams, R.L. \& Williams, D.F. (1999) The corrosion behaviour of Ti-6Al-4V, Ti-6Al-7Nb and Ti-13Nb-13Zr in protein solutions. Biomaterials, 20, pp. 631-637

Kirbs, A.; Lange, R.; Nebe, B.; Rychly, R.; Baumann, A.; Neumann, H.G. \& Beck, U. (2003) Methods for the physical and chemical characterisation of surfaces of titanium implants. Materials Science and Engineering C, 23, 425-429

Lin, H-Y. \& Bumgardner, J.D. (2004) Changes in surface composition of the Ti-6Al-4V implanet alloy by cultured macrophage cells. Applied Surface Science, 225, pp. 21-28

Lin, H-Y. \& Bumgardner, J.D. (2004) In vitro biocorrosion of Co-Cr-Mo implanet alloy by macrophage cells. Journal of Orthopaedic Research, 22, pp. 1231-1236

Liu, C.; Bi, Q. \& Matthews, A. (2003) Tribological and electrochemical performance of PVD TiN coatings on the femoral head of Ti-6Al-4V artificial hip joints. Surface and Coatings Technology, 163-164,pp. 597-604

Macdonald, D.D.; Sikora, E. \& Engelhardt, G. (1998) Characterizing electrochemical systems in the frequency domain. Electrochimica Acta, 43, pp. 87-107

Marino, C-E.B.; Biaggio, S.R.; Rocha-Filho, R.C. \& Bocchi, N. (2006) Voltammetric stability of anodic films on the Ti6Al4V alloy in chloride medium. Electrochimica Acta, 51, pp. 6580-6583

McDowell, O.J. (1953) Fretting corrosion tendencies of several combinations of materials, Symposium on fretting corrosion, ASTM Philadelphia, pp. 40-53.

Munoz, A.I. \& Mischler, S. (2007) Interactive Effects of Albumin and Phosphate Ions on the Corrosion of CoCrMo Implanet Alloy. Journal of The Electrochemical Society, 154, pp. C562-C570

Orazem, M. (2004) Systematic approach toward error structure identification for impedance spectroscopy. Journal of Electroanalytical Chemistry, 572, pp. 317-327.

Oshida, Y. (2007) Implanet-Related Biological Reactions, In: Bioscience and Bioengineering of Titanium Materials, Elsevier, pp. 157-214, Oxford UK

Ouerd, A.; Alemany-Dumont, C.; Berthomé, G.; Normand, B. \& Szunerits, S. (2007) Journal of The Electrochemical Society. 154, pp. C593-C601

Ouerd, A.; Alemany-Dumont, C.; Normand, B. \& Szunerits S. (2008) Reactivity of CoCrMo alloy in physiological medium: Electrochemical characterization of the metal/protein interface. Electrochimica Acta 53, pp. 4461-4469

Pan, J.; Thierry, D. \& Leygraf, C. (1996) Integrated AFM and SCEM for in situ studies of localized corrosion of $\mathrm{Al}$ alloys. Electrochimica Acta, 41, pp. 1143-1153 
Park, J.B. \& Lakes, R.S. (1992) Biomaterials an Introduction, 2nd ed. Plenum Press, pp. 83-88, New York

Payet, V.; Brunner, S.; Galtayries, A.; Frateur, I. \& Marcus P. (2008) Cleaning of albumincontaminated Ti and Cr surfaces: an XPS and QCM study. Surf. Interface Anal, 40, pp. 215-219

Pellier, J.; Geringer, J. \& Forest, B. (2011) Fretting-corrosion between 316L SS and PMMA. Influence of ionic strength, protein and electrochemical conditions on material wear. Application to orthopedic implants. Wear in press

Pertile, L.B.; Silva, P.M.S; Peccin, V.B.; Peres, R.; Silveira, P.G.; Giacomelli, C.; Giacomelli, F.C.; Fredel, M.C. \& Spinelli, A. (2008) In vivo human electrochemical properties of a NiTi-based alloy (Nitinol) used for minimally invasive implants. Journal of Biomedical Materials Research Part A, 89, pp. 1072-1078

Steinemann, S.G. (1980) Evaluation of Biomaterials-Corrosion of Surgical Implants-in vivo and in vitro tests, In: G.D. Winter, J.L. Leray, K. de Groot, John Wiley \& Sons Ltd, pp. 2-33, New York USA

Tamilselvi, S.; Raman, V. \& Rajendran N. (2006) Corrosion behaviour of Ti-6Al-7Nb and Ti$6 \mathrm{Al}-4 \mathrm{~V}$ ELI alloys in the simulated body fluid solution by electrochemical impedance spectroscopy. Electrochimica Acta, 52, pp. 839-846

Tomlinson, G.A. (1927) The rusting of steel surfaces in contact. Proc. Roy. London Ser. A., 115, pp. $472-483$

Tomlinson, G.A.; Thorpe, P.L. \& Gough, H.J. (1939) An investigation of fretting corrosion of closely fitting surfaces. Proceedings of the Institution for Mechanical Engineers, 141, pp. 223-249

Uhlig, H.H. (1954) Mechanism of fretting corrosion. Journal of Applied Mechanics, 21, pp. 401407

Uhlig, H.H. (1979) Passivity in metals and alloys. Corrosion Science, 19, pp. 777-791

Valero, C. \& Munoz, A.I. (2008) Electrochemical characterisation of biomedical alloys for surgical implants in simulated body fluids. Corrosion Science, 50, pp. 1954-1961

Waterhouse, R.B. (1955) Fretting corrosion. Proceedings of the Institution for Mechanical Engineers, 169, pp. 1159-1172

Waterhouse, R.B. (1977) The role of adhesion and delamination in the fretting wear of metallic materials. Wear, 45, pp. 355-364

Waterhouse, R.B. \& Lamb, M. (1980) Fretting corrosion of orthopaedic implanet materials by bone cement. Wear, 60, pp. 357-368

Williams, R.L.; Brown, S.A. \& Merritt, K. (1988) Electrochemical studies on the influence of proteins on the corrosion of implanet alloys. Biomaterials, 9, pp. 181-186

Yan, H.; Xiaoying, L.; Jingwu, M. \& Nan H. (2008) In vitro investigation of protein adsorption and platelet adhesion on inorganic biomaterial surfaces. Applied surface Science, 255, pp. 257-259

Yuen, C.K. \& Ip, W.Y. (2010) Theoretical risk assessment of magnesium alloys as degradable biomedical implants. Acta Biomaterialia, 6, pp. 1808-1812

Zaveri, N.; Mahapatra, M.;. Deceuster, A.; Peng, Y; Li, L. \& Zhou A. (2008) Corrosion resistance of pulsed laser-treated Ti-6Al-4V implanet in simulated biofluids, Electrochimica Acta, 53, pp. 5022-5032 


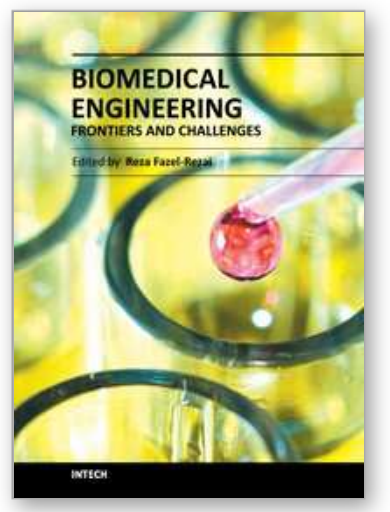

\author{
Biomedical Engineering - Frontiers and Challenges \\ Edited by Prof. Reza Fazel
}

ISBN 978-953-307-309-5

Hard cover, 374 pages

Publisher InTech

Published online 01, August, 2011

Published in print edition August, 2011

In all different areas in biomedical engineering, the ultimate objectives in research and education are to improve the quality life, reduce the impact of disease on the everyday life of individuals, and provide an appropriate infrastructure to promote and enhance the interaction of biomedical engineering researchers. This book is prepared in two volumes to introduce recent advances in different areas of biomedical engineering such as biomaterials, cellular engineering, biomedical devices, nanotechnology, and biomechanics. It is hoped that both of the volumes will bring more awareness about the biomedical engineering field and help in completing or establishing new research areas in biomedical engineering.

\title{
How to reference
}

In order to correctly reference this scholarly work, feel free to copy and paste the following:

Geringer Jean and Navarro Laurent (2011). Role of Proteins on the Electrochemical Behavior of Implanted Metallic Alloys, Reproducibility and Time-Frequency Approach from EIS (Electrochemical Impedance Spectroscopy), Biomedical Engineering - Frontiers and Challenges, Prof. Reza Fazel (Ed.), ISBN: 978-953307-309-5, InTech, Available from: http://www.intechopen.com/books/biomedical-engineering-frontiers-andchallenges/role-of-proteins-on-the-electrochemical-behavior-of-implanted-metallic-alloys-reproducibility-and-ti

\section{INTECH}

open science | open minds

\section{InTech Europe}

University Campus STeP Ri

Slavka Krautzeka 83/A

51000 Rijeka, Croatia

Phone: +385 (51) 770447

Fax: +385 (51) 686166

www.intechopen.com

\section{InTech China}

Unit 405, Office Block, Hotel Equatorial Shanghai

No.65, Yan An Road (West), Shanghai, 200040, China

中国上海市延安西路65号上海国际贵都大饭店办公楼 405 单元

Phone: +86-21-62489820

Fax: +86-21-62489821 
(C) 2011 The Author(s). Licensee IntechOpen. This chapter is distributed under the terms of the Creative Commons Attribution-NonCommercialShareAlike-3.0 License, which permits use, distribution and reproduction for non-commercial purposes, provided the original is properly cited and derivative works building on this content are distributed under the same license. 